\title{
Emotional Intelligence, Work Engagement, and Organizational Commitment of Indonesian Army Personnel
}

\author{
Aulia \\ Faculty of Psychology \\ Universitas Ahmad Dahlan
}

\begin{abstract}
The aim of this study was to empirically test the relationship between emotional intelligence, work engagement, and organizational commitment Indonesian Army personnels. A quantitative research method was used, utilizing scales of organizational commitment, emotional intelligence, and work engagement. Indonesian Army personnels of KOREM XX, KODIM, YY, and KODIM ZZ were the population of this study. Data analysis using regression techniques revealed an $R$ value of $.482(p<.001)$. This showed a significant relationship between emotional intelligence, work engagement, and organizational commitment. In addition, partial correlation analysis showed a significant relationship between work engagement and organizational commitment $(r=.447$ and $p<.001)$, but there was no significant relationship between emotional intelligence and organizational commitment $(r=$ .129 and $p>.05$ ). Effective contribution of work engagement on organizational commitment of the Indonesian Army personnel was 23.2\%.
\end{abstract}

Keywords: organizational commitment, emotional intelligence, work engagement, army personnel

Tujuan penelitian ini adalah menguji secara empiris hubungan kecerdasan emosi dan keterikatan kerja, dan komitmen organisasi TNI AD melalui pendekatan kuantitatif menggunakan skala komitmen organisasi, skala kecerdasan emosi, dan skala keterikatan kerja. Populasi adalah para personel TNI AD yang bertugas di KOREM XX, KODIM YY, dan KODIM ZZ. Analisis data dengan teknik regresi, menghasilkan nilai $R=.482$ dengan $p<$ .001 . Hal ini menunjukkan bahwa terdapat hubungan yang sangat signifikan antara kecerdasan emosi, keterikatan kerja, dan komitmen organisasi. Hasil analisis korelasi parsial menunjukkan adanya hubungan yang sangat signifikan antara keterikatan kerja dan komitmen organisasi $(r=.447$ dan $p<.001)$, namun tidak ada hubungan yang signifikan antara kecerdasan emosi dan komitmen organisasi $(r=.129$ dan $p>.05)$. Sumbangan efektif keterikatan kerja terhadap komitmen organisasi personel TNI AD adalah sebesar 23.2\%.

Kata kunci: komitmen organisasi, kecerdasan emosi, keterikatan kerja, personel angkatan darat

National defence is a core element of the existence of a nation. Based on Undang-Undang (Law) No. 34, 2004, it was stated that TNI (Indonesian Military Forces) has a major role in its function to defend the country as well as to carry out national duties and political decisions. TNI as means of national defense functions as a resistance to any form of military and weaponized threats from outside and within the country. The main task of TNI is to up-

Correspondence concerning this article should be addressed to Aulia, Faculty of Psychology, Universitas Ahmad Dahlan, Jalan Kapas 9, Semaki Umbulharjo, Yogyakarta 55166. E-mail: auliazenlovemail@ gmail.com hold the sovereignty of the nation, preserve the integrity of the Republic of Indonesia based on Pancasila and Undang-Undang Dasar Negara Republik Indonesia 1945 (Indonesian Constitution), and protect the nation and its citizens from threats and disruptions. Such task is divided into two, which are war-related military operations and non-war-related military operations.

Non-war military operations include activities such as addressing armed separatist movements, armed revolts, acts of terror, securing border regions, securing strategic vital national objects, carrying out actions for world peace according to foreign policies, 
securing the President and Vice President and their families, helping the Indonesian National Police in their duty to uphold civil security as regulated by the law, ensuring the security of national guests at the level of the head of the nation and foreign representatives in Indonesia, addressing the aftermath of natural disasters, refugee actions and humanitarian aid, search and rescue, and aiding the government in seafaring and aviation security against piracy and smuggling.

Such difficult operations have been found to have negative consequences on the behaviour and attitude of personnels. Moeldoko (cited in Hakim, 2015) stated that the amount of desertion in TNI soldiers increased up to 62 cases, from 865 cases in JanuarySeptember 2013 period to 927 cases in the same period in 2014. Based on his experience as a Korem Commander, Moeldoko also said that one reason why desertion occurred is the lack of mental preparation from soldiers going into a battalion and the resulting experience of mental pressure.

Such facts also indicate that the level of commitment of personnels in an organization is related to their ability to manage, organize, and cope with demands and environmental pressure that can directly affect their psychological welfare. This ability is considered by Bar-On (2002) as emotional intelligence. This is in accordance with the statement by Abrahams (2007) indicating that armed forces require soldiers who are capable of quickly adapting to ambiguous and dangerous situations. This quality is marked by emotional intelligence in adapting and ability to manage stress. This means that it can be assumed that emotional intelligence is an important quality for personnels that may contribute to their level of organizational commitment.

Other factors contributing to the act of desertion have been stated by the Central Commander of Military Police, Major General Sulaiman (Juminatun, Amin \& Effendy, 2005). These include financial difficulty and unpleasant unit environment such as restricted leave. However, most were caused by financial issues, and this forces military personnels to do work outside of the military environment. This is in line with the study by Langkamer and Ervin (2008) who found that psychological climate influences the affective commitment of army members to stay with or leave the organization. Alarcon, Lyons, and Tartaglia (2010) showed that the commitment of military personnel towards the organization is influenced by their work engagement, and that one reason why military personnel desert their rank is to "fix" their work situation.
From the earlier explanation, the current study aims to observe the relationship between emotional intelligence and work engagement on organizational commitment of TNI AD personnels. Based on the review done by the author on relevant literature, there is a lack of research discussing the relationship between emotional intelligence and work engagement on organizational commitment in a military context, specifically in Indonesia. Therefore, it can be argued that this current study is important in enriching the field of industrial and organizational psychology, in particular military psychology in Indonesia.

Meyer and Herscovitc (2002) explained that organizational commitment is emotional engagement, identification and individual involvement with the organization as well as the desire to still be considered as an employee. Research showed that employees with higher level of organizational commitment had better relationship with peers, higher satisfactions, lower absenteeism and turnover rates, as well as better work performance compared to those with lower organizational commitment (Bateman \& Strasser, 1984; Suliman, 2002, Obeng \& Ugboro, 2003). It can be seen that organizational commitment is an important quality to have especially in the military environment, because personnels with commitment will show willingness to work hard to achieve organizational goals, and possess greater desire to keep working in the organization.

In general, Meyer, Allen, and Smith (1993) considered commitment as a psychological condition that characterizes the relationship between employees and the organization, and has the implication on the decision to continue or stop working in the organization. Commitment is also related to employee engagement to the organization (Akroyd, Legg, Jackowski, \& Adams, 2009; Nguyen, Mai, \& Nguyen, 2014).

Meyer and Allen (1991) stated three dimensions of organizational commitment, that include:

(a) Affective commitment, which refers to emotional attachment, identification, and involvement of an employee to the organization. Affective commitment strengthens when an employee's experience in an organization is consistent with his/her goals and satisfies his/her basic needs, and vice versa. Affective commitment shows the strength of an employee's desire to work for an organization because their goals are in alignment with the organization. Employees with strong affective commitment will continue working in the organization because they want to work there.

(b) Continuence commitment, this commitment re- 
fers to consideration of potential loss incurred by the employee when he/she stops working in the organization. This may occur due to the loss of status, promotions, or benefits. The concept of side-bets orientation highlights the contribution of an employee that may be taken away when he/she leaves the organization. Leaving is therefore a high-risk action because employees feel that they will lose their investment in the organization, and they realize that it may be difficult to find an appropriate substitute.

(c) Normative commitment, this relates to feeling responsible to stay in an organization because it is the right thing to do.

According to Salami (2008), another factor that influences individual commitment to an organization is emotional intelligence. Research by Boshoff and Arnolds (1995) showed that employees with high emotional intelligence also had higher levels of organizational commitment. This finding is supported by Thapisa and Jain (2000) and Suzyanti, Wan, and Norsamsinar (2005) who found a relationship between emotional intelligence and organizational commitment.

Goleman (2001) stated that emotional intelligence refers to the ability to acknowledge individual emotions as well as the emotion of others, to motivate oneself, and in their relation with others that can be done through self-awareness, self-restraint, self-motivation, empathy, and social skills. Therefore, emotional intelligence includes skills that are different to, but complements with, intellectual intelligence.

Unlike other authors, Salovey and Mayer (1990) considered emotional intelligence as the capacity to understand, regulate, and utilize emotions. On the other hand, Bar-On (2002) explained emotional intelligence as a set of abilities, competencies, and skills that may affect an individual's success in dealing with demands, environmental pressure, and directly affects psychological wellness. Bar-On's emotional intelligence includes:

\section{Intrapersonal Variables}

Including self-awareness and understanding of strength and weaknesses, expression of the self, feeling, and mind in a non-destructive way. Intrapersonal components consist of:

Self-regard. Individual ability to be aware, understand, accept themselves in their positive and negative ways, and their own limitations.

Emotional self-awareness. An individual's ability to be aware and be familiar with feelings and self-emotions; sorting out emotions, understanding what is felt, and also why the emotion occurs.

Assertiveness. An individual's ability to express his/her feelings without being destructive.

Independence. An individual's ability to be confident and free from emotional dependency on others.

Self actualization. The ability to realize someone's potential through a dynamic and continuous process; trying to develop abilities, skills, and talent to the maximum.

\section{Interpersonal Variables}

Individual skill to be aware of emotions, feelings, and needs of others. Ability to create and maintain cooperative, constructive, and mutually beneficial relationship with others. This component consists of:

Empathy. Individual ability to be aware of, understand, and respect the feelings of others. Being sensitive to what, how, and why others feel. Able to "read" other people's emotions. Those with empathy shows care and attention to others.

Social responsibility. Individual ability to function as a cooperative member, providing constructive contributions to a social group. This component relates to the ability to do something to and/or with others, accepting others, behaving according to conscience and upholding social norms. The displayed ability is interpersonal sensitivity and ability to use skills for collective goals, and not just for individuals.

Interpersonal relationship. Interpersonal relationship is an individual skill that involves the ability to develop and maintain mutually beneficial relationship with others, and this is marked with intimacy, giving and receiving affection. This skill requires sensitivity towards others, need to build a satisfying relationship. Developing mutually satisfying relationship with others.

\section{Stress Management Variable}

The ability to manage stress so it becomes beneficial and not detrimental to oneself. This component includes:

Stress tolerance. Stress tolerance is an individual's ability to persevere in a stressful and difficult situation, and the ability to actively and positively handle the situation. This means that the individual can effectively and constructively manage emotions.

Impulse control. This is the ability to stop or de- 
lay impulsiveness, drive and temptation to act a certain way. This means that the individual can effectively and constructively manage emotions.

Empirical evidence showed that work engagement in the army increases work prestige, performance, organizational behavior, productivity, discretionary effort, affective commitment, continuence commitment, psychological climate, and customer service (Christian, Garza, \& Slaughter, 2011; Fleming \& Asplund, 2007; Rich, Lepine, \& Crawford, 2010; Richman, 2006). This means that individuals with low work engagement tend to waste their energy for useless activities so that whatever they do can never support organizational performance, and increasing work engagement is important for organizational productivity.

Harter, Schmidt, and Hayes (2002) explained work engagement as individual involvement with the satisfaction and enthusiasm towards work. Work engagement is related to persistence, positive affect of motivation to meet the needs of employees. This is indicated by high level of activity and sense of fulfillment (Schaufeli et al., 2006, as cited in Maslach, Schaufeli, \& Leiter, 2001).

Saks (2006) explained work engagement as a unique and distinct construct consisting of cognitive, emotional, and behavioral aspects related to individual performance. Schaufeli, Salanova, González-Romá, and Bakker (2002) and Schaufeli, Bakker, and Salanova, M. (2006) stated the dimensions of work engagement that include: (a) Vigor, indicated by energy and mental fortitude at work, willingness to put effort at work, and persistence in dealing with obstacles; (b) Dedication, a condition when someone is involved, enthusiastic, proud, feels meaningful, inspired, and challenged in their work; (c) Absorption, a condition where someone gladly and attentively become linked with his/her job, feeling that time goes by really fast and has a difficulty separating himself/herself with the job (Schaufeli et al., 2006).

From the explanations earlier, it was hypothesized that emotional intelligence and work engagement positively affects organizational commitment. In other words, as emotional intelligence and work engagement of TNI AD personnel increases, so will their organizational commitment. Conversely, lower emotional intelligence and work engagement will be associated with low organizational commitment.

\section{Method}

This study used quantitative methods with a cor- relational approach. Prior to data collection, the author extensively reviewed the literature, prepared the measurements to be used and performed the necessary clearance checks. The population in this study was TNI AD personnel, while the samples specifically are TNI AD personnel assigned to the KOREM XX unit.

The study was done using previously tested measurement tools that include organizational commitment scale by Allen and Meyer revised by Jaros (2007), emotional intelligence scale by Bar-On (2002), and work engagement scale using Utrecht Work Engagement Scale (UWES) by Schaufeli and Bakker (2003). Data was collected for each unit starting from KOREM XX which had a total of 58 personnels, and the week after on KODIM YY which had 71 personnels, and lastly KODIM ZZ which had 69 personnels, making a total sample size of 198 personnels. Prior to giving their responses to the measurement, however, the researchers asked participants to sign a clearance form to indicate their willingness to participate in the study.

Reliability testing was done following data collection, using Cronbach's alpha formula. Results of this test showed the following reliability coefficients: organizational commitment with $\alpha=.780$; emotional intelligence with $\alpha=.846$, and work engagement with $\alpha=.862$. These scores indicated that the measurement tools are reliable enough for the data collection results to be used to test the hypothesis.

\section{Results}

Multiple regression analyses based on the scales of emotional intelligence, work engagement, and organizational commitment using 198 TNI AD personnels as samples showed an $F$-value of 29.429 with a significance value of $.000(p<.001)$, with $R$ $=.482, R^{2}=.232$ and a significance of $p=.000(p<$ $.001)$. This showed a significant positive relationship between emotional intelligence and work engagement with organizational commitment (hypothesis was accepted).

Partial correlation analysis results showed that emotional intelligence was not significantly related to organizational commitment $\left(r_{x I y}\right)$, with $r=.129$ and $p=.071(p>.05)$, whereas work engagement was found to have a significant positive relationship with organizational commitment $\left(r_{x 2 y}\right), r=.447$ and $p=.000(p<.001)$. This means that as the personnels' level of work engagement increases, so will 
their organizational commitment. Conversely, lower levels of work engagement are associated with lower levels of organizational commitment. Results showed an effective contribution of $23.2 \%$ from the $R^{2}$. This was assumed to originate from the work engagement variable, not emotional intelligence, because partial correlation analysis results did not show any significant relationship between emotional intelligence and organizational commitment.

\section{Discussion}

Findings of the current study showed that emotional intelligence was not an important factor for TNI AD personnels' organizational commitment. Differences in the level of emotional intelligence has no relationship at all with their decision to leave or stay with the organization. This particular result showed that the study assumption that emotional intelligence is a key factor in influencing organizational commitment of TNI AD personnels was not supported.

In addition, Abrahams' (2007) explanation regarding the importance of emotional intelligence in adapting and the ability to manage stress can be argued to be only applicable in leadership development in military organization, not in increasing the commitment of army personnels. This is also in line with Suyono, Aulia, and Tentama (2015) who found that emotional intelligence was related to transformational leadership. This means that the findings of the current study showed different results in a military organization compared to other studies conducted in non-military organizations, such as those by Boshoff and Arnolds (1995), Thapisa and Jain (2000), and Suzyanti et al. (2005) who found that employees with higher emotional intelligence also had higher organizational commitment.

The contrasting finding between the current study and previous literature may have occurred due to differences in system, culture, and characteristics of military organizations compared to non-military general organizations. Such differences led to the assumption that there are other more important variables than emotional intelligence that influences TNI AD personnel's decision to stay in the organization. One example is the fact that TNI AD is a military institution with a direct responsibility to the nation and its people. This example is in line with Huntington's (1957) regarding three aspects of professional military work, which include expertise, group, and most importantly social responsibility. The social responsibility of a military professional is to protect the citizen and the country.

This form of social responsibility is in accordance with the soldier's oath in article 35 UndangUndang No. 34 year 2004 about the Indonesian National Army (TNI) and expressed in the oath highlighting that TNI is expected to perform their duty as a form of obedience, compliance in respecting and carrying out a system based on submission to decision, orders, or regulations that are put in place. Just like work is being done as a form of employee devotion to their superior, country, and love of the nation, despite having to put aside individual needs, all of these things are done as part of their commitment in their work as Indonesian National Army. This means that obedience, submission, or acceptance of decisions and regulations that are in effect is one form of TNI's social responsibility towards the citizen and the nation.

On the other hand, the present study also yielded results that indicate the relationship between work engagement and the commitment of TNI AD personnels on the organization. This finding supported the results of the research by Alarcon, Lyons, and Tartaglia (2010) who found that the commitment of military personnels is affected by work engagement. Similarly, Beatty (2011) explained how the work engagement of Canadian soldiers was empirically found to predict work satisfaction, performance, and decision to stay or leave the organization.

Findings of the present study support the relationship between work engagement and organizational commitment, and strengthens previous theory and research done in non-military organizations. This is similar to the study by Rothmann and Jordaan (2006) who found a positive correlation between work engagement and organizational commitment. Work engagement is also an antecedent of organizational commitment because people who are involved or engaged with their work tend to be more committed to the organization (Jackson, Rothmann, \& Van de Vijver, 2006; Saks, 2006).

Empirically, work engagement was shown to be correlated with organizational commitment. However, commitment of TNI AD personnels is not a one-sided phenomenon. In this case, the organization along with TNI AD personnels cooperate together to create a conducive environment to achieve commitment. This idea is supported by Beatty's (2011) Canadian soldier study, where it was found that work engagement is an important construct to be 
considered when observing work-related behavior.

Nevertheless, the organization also needs to nurture personnel engagement to increase their organizational commitment. It is important for commandants or supervisor to understand important causes and consequences that can stimulate work engagement. This can be done by conditioning or creating a warm, fun environment to elicit happiness at work. This should hopefully create a positive effect on TNI AD personnels and the organization, because engagement does not only increase organizational commitment, but also intrinsic motivation, work satisfaction, turnover intention (Kreitner \& Kinicki, 2014) as well as happiness (Coetzee \& Rothmann, 2005; Jackson, Rothmann, \& Van de Vijver, 2006; Rothmann \& Jordaan, 2006).

\section{Limitations}

The limitations of the present study include control and selection of the samples. Some issues that can theoretically influence organizational commitment include physical characteristics such as gender, age, education, marital status, degree, and work tenure (Dodd- McCue \& Wright, 1996; Mannheim, Baruch, \& Tal, 1997; Morrow, 1993) as well as psychological characteristics such as personality type (Mathieu \& Zajac, 1990), workplace stress (Vakola \& Nikolaou, 2005; Ziauddin, Khan, Jam, \& Hijazi, 2010), work satisfaction (Malik, Nawab, Naeem, \& Danish, 2010). This means that there are numerous other variables that can influence the results of this study. Therefore, future studies should investigate those variables, especially those that have been theoreticcally indicated to have an influence on the commitment of TNI AD personnels on the organization.

\section{Conclusion}

Based on the findings, it can be concluded that there is a relationship between emotional intelligence and work engagement with organizational commitment of TNI AD personnels. However, emotional intelligence was not found to have a direct influence on organizational commitment. Work engagement had an effective contribution of $23.2 \%$ on organizational commitment. This means that higher work engagement will increase TNI AD personnels' commitment to their organization, and conversely lower engagement will lead to weaker organizational commitment.
The Utrecht Work Engagement Scale (UWES) from Schaufeli and Bakker have often been used to observe general work engagement, as seen in studies by Schaufeli et al. (2002), Hallberg and Schaufeli (2006), and Schaufeli, Bakker, and Salanova (2006). It was also shown in previous study that the UWES scale can be adapted to function in a military-based organization (Beatty, 2011). However, out of the 17 original items, one had to be removed. Future studies are encouraged to create another item to complete the scale. The present study has extended the findings of previous studies as well.

\section{References}

Abrahams, D. S. (2007). Emotional intelligence and army leadership: Give it to me straight! Military Review, 2, 86-93.

Akroyd, D., Legg, J., Jackowski, M., \& Adams, R. (2009). The impact of selected organizational variables and managerial leadership on radiation therapists organizational commitment. Radiography, $15,113-120$.

Alarcon, G., Lyons, J. B., \& Tartaglia, F. (2010). Understanding predictors of engagement within the military. Military Psychology, 22(3), 301.

Bar-On, R. (2002). Bar-On emotional quotient inventory: Short technical manual. Toronto, Canada: Multi-Health Systems.

Bateman, T. S., \& Strasser, S. (1984). A longitudenal analysis of the antecedents of organizational commitment. Academy of Management Journal, 27(1), 95-96.

Beatty, P. (2011). Engagement, organizational commitment, and incremental variance in the measurement of job satisfaction, performance and turnover intent within the Canadian forces (Unpublished Thesis). Carleton University. Ottawa, Ontario.

Boshoff, C., \& Arnolds, C. (1995). Some antecendents of employee commitment and their influence on job perfomance. South African Journal of Business Management, 26, 125-144.

Christian, M. S., Garza, A. S., \& Slaughter, J. E. (2011). Work engagement: A quantitative review and test of its relations with and contextual performance. Personnel Psychology, 64, 89-136.

Coetzee, S. E., \& Rothmann, S. (2005). Work Engagement of employees at a higher education institution in South Africa. Southern African Business Review, 9(3), 23-34. 
Dodd-McCue, D., \& Wright, G. B. (1996). Men, women, and attitudinal commitment: The effects of workplace experiences and socialization. Human Relations, 49(8), 1065-1091.

Fleming, J. H., \& Asplund, J. (2007). Human sigma. New York, NY: Gallup Press.

Hakim, S. (2015). Panglima TNI: Jumlah prajurit yang desersi meningkat. Retrieved from http:// www.antaranews.com

Hallberg, U. E., \& Schaufeli, W. B. (2006). "Same same" but different? Can work engagement be discriminated from job involvement and organizational commitment? European Psychologist, 11 (2), 119-127.

Huntington, S. (1957). The soldier and the state: The theory and politics of civil-military relations. Cambridge: Belknap Press of Harvard University Press.

Goleman, D. (2001). An EI-based theory of performance. The emotionally intelligent workplace: How to select for, measure, and improve emotional intelligence in individuals, groups, and organizations, 1, 27-44.

Harter, J. K., Schmidt, F. L., \& Hayes, T. L. (2002). Business-Unit-Level Relationship between Employee Satisfaction, Employee Engagement, and Business Outcomes: A Meta-Analysis. Journal of Applied Psychology, 87, 268-279.

Jackson, L. T. B., Rothmann, S., \& Van de Vijver, F. J. R. (2006). A model of work-related wellbeing for educators in South Africa. Stress and Health, 22, 263-274.doi:10.1002/smi.1098

Jaros, S. (2007). Meyer and Allen model of organizational commitment: Measure-ment issues. The Icfai 8 Journal of Organizational Behavior, 6(4), 7-25.

Juminatun, E., Amin, N., \& Effendy, S. (2005). Ketahanan mental prajurit TNI AD dan implykasinya bagi ketahanan HANKAM. Jurnal Sosiosains, 18(2), 387-397.

Kreitner, R., \& Kinicki, A. (2014). Perilaku organisasi (9th ed., Book 1, Biro Bahasa Alkemis, Pengalih bhs). Jakarta: Salemba Empat.

Langkamer, K. L., \& Ervin, K. S. (2008). Psychological climate, organizational commitment and morale: Implications for Army captains' career intent. Military Psychology, 20(4), 219.

Malik, M. E., Nawab, S., Naeem, B., \& Danish, R. Q. (2010). Job satisfaction and organizational commitment of university teachers in public sector of Pakistan. International Journal of Business and Management, 5(6), 17-26.
Mannheim, B., Baruch, Y., \& Tal, J. (1997). Alternative models for antecedents and outcomes of work centrality and job satisfaction of high-tech personnel. Human Relations, 50(12), 1537-1562.

Maslach, C., Schaufeli, W. B., \& Leiter, M. P. (2001). Job Burnout. Annual Review of Psychology, 52, 397-422.

Mathieu, J. E., \& Zajac, D. M. (1990). A review and meta-analysis of the antecedents, correlates, and consequences of organizational commitment. Psychological bulletin, 108(2), 171.

Meyer, J. P., \& Allen, N. J. (1991). A three-component conceptualization of organizational commitment. Human Resource Management Review, 1, 61-89.

Meyer, J. P, Allen, N. J., \& Smith, C. (1993). Commitment to Organizations and Occupations: Extension and Test of a Three-Component Conceptualization, Journal of Applied Psychology, 78, 538-551.

Meyer, J. P., \& Herscovitc, L. (2002). Commitment to organization change: Extension of a threecomponent model. Journal of Applied Psychology, 73, 474-487.

Morrow, P. (1993). The theory and measurement of work commitment. Greenwich, CT: JAL.

Nguyen, T. N., Mai, K. N., \& Nguyen, P. V. (2014). Factor affecting employees' organizational commitment-a study of banking staff in Ho Chi Minh Ccity, Vietnam. Journal of Advanced Management Science, 2(1), 7-11.

Obeng, K., \& Ugboro, I. (2003). Organizational commitment among public transit employees: An assessment study. Journal of the Transportation Research Forum, 5(2), 83-98.

Rich, B. L., \& Lepine, J. A., \& Crawford, E. R. (2010). Job Engagement: Antecedents and Effects on Job Performance. Academy of Management Journal, 53, 617-635.

Richman, A. (2006). Everyone wants an engaged workforce: How can you create it? Workspan, 49, 36-39.

Rothmann, S., \& Jordaan, G. M. E. (2006). Job demands, job resources and work engagement of academic staff in South African higher education institutions. SA Journal of Industrial Psychology, 32(4), 87-96.

Saks, A. M. (2006). Antecedents and consequences of employee engagement. Journal of Managerial Psychology, 21, 600-619.

Salami, S. O. (2008). Demographic and psychological factors predicting organizational commit- 
ment among industrial workers. Anthropologist, 10(1), 31-38.

Salovey, P., \& Mayer, J. D. (1990). Emotional intelligence. Imagination, cognition and personality, 9(3), 185-211.

Schaufeli, W. B., Salanova, M., González-Romá, V., \& Bakker, A. B. (2002). The measurement of engagement and burnout: A confirmative analytic approach. Journal of Happiness Studies, 3, 71-92

Schaufeli, W. B., \& Bakker, A. B. (2003). Utrecht work engagement scale: Preliminary manual. Occupational Health Psychology Unit. Utrecht University.

Schaufeli, W. B., Bakker, A. B., \& Salanova, M. (2006). The measurement of work engagement with a short questionnaire: A cross-national study. Educational \& Psychological Measurement, 66, 701-716.

Suliman, A. M. T. (2002). Is it really a mediating construct? The mediating role of organizational commitment in work climate-performance rela- tionship. Journal of Management Development, 21(3), 170-183.

Suyono, H., Aulia, \& Tentama, F. (2015). Leadership of Indonesian Armed Forces. Laporan Penelitian Kerjasama Kelembagaaan. Fakultas Psikologi Universitas Ahmad Dahlan. Yogyakarta.

Suzyanti, M. H., Wan, S. W. M., \& Norsamsinar, S. (2005). Kepuasan kerja kakitangan akademik: Satu perbandingan jantina. Kertas Kerja Bagi Pembentangan Persidangan Psikologi Malaysia.

Thapisa, A. P. N., \& Jain, P. (2000). Bio-factor analysis of library productivity. Library Management, 21(2), 86-93.

Vakola, M., \& Nikolaou, I. (2005). Attitudes towards organizational change: What is the role of employees' stress and commitment? Employee relations, 27(2), 160-174.

Ziauddin, I., Khan, M., Jam, F., \& Hijazi, S. (2010). The impacts of employees' job stress on organizational commitment. European Journal of Social Sciences, 13(4), 617-622. 